Article - Biological and Applied Sciences

\title{
Effect of Salicylic Acid, 2,4-D and 2i-P on the Production of Secondary Metabolites in Garcinia brasiliensis Mart. Callus
}

\author{
Maria Gessi Teixeira ${ }^{1}$ \\ https://orcid.org/0000-0002-2232-0887 \\ Marília Carvalho ${ }^{2}$ \\ https://orcid.org/0000-0002-2251-0234 \\ Marco Aurélio Leite ${ }^{3}$ \\ https://orcid.org/0000-0002-5525-3107

\section{Sandro Barbosa²} \\ http://orcid.org/0000-0001-7321-0007
}

Plinio Rodrigues dos Santos filho ${ }^{3}$

http://orcid.org/0000-0001-8530-1977

\section{Breno Régis Santos ${ }^{2}$}

http://orcid.org/0000-0002-3980-9013

${ }^{1}$ Federal Institute of Education, Science and Technology of South of Minas Gerais, Machado, Minas Gerais, Brasil; ${ }^{2}$ Federal University of Alfenas, Institute of Natural Sciences, Alfenas, Minas Gerais, Brasil; ${ }^{3}$ Institue of Biomedical Sciences, Biochemistry department, Alfenas, Minas Gerais, Brasil.

Received: 2017.05.02; Accepted: 2019.05.19

* Correspondence: pliniosant@hotmail.com; Tel.: +55-35-3701-9560 Plinio Rodrigues

\section{HIGHLIGHTS}

- Bacupari callus presents significative levels os phenolics and flavonoids.

- Specifically, it was idenficated fukugetin e 7-epiclusianone

- Growth regulators and salicylic acid affected the occurrence these substances.

Abstract: The aim of this work was to evaluate the effect of Salicylic acid, 2,4-D and 2-iP on the production of total phenolic and flavonoids as well in the levels of fukugetin and 7-epiclusianone in callus of Garcinia brasiliensis zygotic embryos. For this, Bacupari callus 
were exposed to different concentrations $(0.0 ; 0.1 ; 1 ; 10 ; 100 \mu \mathrm{M})$ of Salicylic acid (SA) in the presence or in the absence of $72 \mu \mathrm{M} 2-\mathrm{iP}$ and $28.73 \mu \mathrm{M} 2,4-\mathrm{D}$. The highest concentration of total phenolic occurred in the treatment with $100 \mu \mathrm{M} \mathrm{SA}$ in callus subcultured in the absence of 2,4-D and 2-iP, and with $10 \mu \mathrm{M} \mathrm{SA}$ in callus subcultured in the presence of these regulators. Concerning flavonoids, 2,4-D and 2-iP supplementation without the presence of the SA was sufficient for the highest levels. Additionally, it was possible to identify the fukugetin and 7-epiclusianone. However, the variation in the levels was very high, especially for the fukugetin. Therefore, in most treatments, there was no statistically difference. Except for the treatment with $10 \mu \mathrm{M} \mathrm{SA}+2,4-\mathrm{D}$ and 2-iP, where there was a significant increase in 7-epiclusianone.

Keywords: Bacupari; phenols; flavonoids; 7-epiclusianone; fukugetin.

\section{INTRODUCTION}

The genus Garcinia has been shown by phytochemical studies to possess a great diversity of secondary metabolites, such as benzophenones, phenolic acids and flavonoids. Many of these compounds are recognized to possess pharmacological properties against various diseases $[1,2,3]$.

In Bacupari, Garcinia brasiliensis Mart, biflavonoids and benzophenones can be highlighted. These componuds are very common in the Garcinia genus [4], having been found in thirty-two species [5,6]. In this context two substances has received great attention, the biflavonoid fukugetin and the tetraprenylated benzophenone 7-epiclusianone. Fukugetin is the most frequent biflavonoid in the Clusiaceae family including being used as chemosysistematic marker [5]. In vitro tests have shown that fukugetin is a potent inhibitor of Trypanosoma cruzi [7] and Leishmania amazonensis [8,9]. It is also has activity against some gram-positive bacteria, such as Escherichia coli, Bacillus cereus, Pseudomonas aeruginosa, Staphylococcus aureus and Staphylococcus saprophyticus [10]. In addition presents anti-inflammatory and anti-oxidant activity [11]. The 7-epiclusianone, isolated for the first time from Rheedia gardneriana Planch. \& Triana fruits [6], has anti-anaphylactic [12], antimicrobial [13], anti-spasmodic [14], anti-proliferative [15] and leishmanicide [16], antinoceptive, antioxidant and cytotoxic [5] activities.

In in vivo plants, secondary metabolites are produced in very small amounts and are generally difficult to extract [17]. Therefore, in vitro plant cell culture has been used for the production of secondary metabolites of interest [18]. One strategy frequently used is the addition of elicitors, such as salicylic acid (SA), in the culture medium of in vitro cell culture [19]. SA acts as a phytohormone [20] and maintains auxin and cytokinin levels in plant tissues, increasing cell division and dry matter [21]. It also activates the enzyme L-phenylalanine ammonia lyase (PAL), which acts between primary and secondary metabolism, involved in the production route of compounds of secondary metabolism [22]. SA also acts on the antioxidant system, regulating various physiological and biochemical processes in plants [23], depending on its concentration, type of plant/explant, plant growth phase and environmental conditions [24]. 
Considering the medicinal properties of Garcinia brasiliensis, the objective of this study was to evaluate the effect of SA, 2,4-D and 2-iP on the total content of phenolics and flavonoids and on the production of fukugetin and 7-epiclusianone in callus obtained from zygotic embryos.

\section{MATERIAL AND METHODS}

\section{Plant Material and Callus Induction}

Garcinia brasiliensis fruits were collected in Viçosa, MG, in the second half of February 2015. The fruits were pulped and their seeds remained for 30 days at a temperature of $22^{\circ} \mathrm{C}$ for drying and subsequent seed coat removal.

For embryo disinfestation, $70 \%$ alcohol was used for 2 minutes and, subsequently, sodium hypochlorite at a concentration of $2.5 \%$ active chlorine for 15 minutes. The embryos were then rinsed for three times in distilled and autoclaved water. This process was carried out in a laminar flow chamber previously sterilized with $70 \%$ alcohol and UV radiation for 20 minutes.

The embryos were transversely segmented and inoculated into 10-cm Petri dishes containing $30 \mathrm{~mL}$ of WPM culture medium [25], with 10 segments per plate. The culture medium was supplemented with $30 \mathrm{~g} \mathrm{~L}^{-1}$ sucrose and $6 \mathrm{~g} \mathrm{~L}^{-1}$ agar, with the combination of 72 $\mu \mathrm{M} 2-\mathrm{iP}+28.73 \mu \mathrm{M} 2,4-\mathrm{D}$. The $\mathrm{pH}$ was adjusted to $5.8 \pm 0.1$ before autoclaving, which was carried out at $121^{\circ} \mathrm{C}$, pressure of $1.0 \mathrm{~atm}$ for a period of 20 minutes.

\section{Callus Subculture and Treatments}

After 45 days of cultivation, the callus were separated from the zygotic embryo segment and inoculated into test tubes containing $20 \mathrm{~mL}$ of WPM culture medium with different concentrations of SA $(0 ; 0.1 ; 1 ; 10 ; 100 \mu \mathrm{M})$ in the presence and in the absence of regulators 2-iP $(72 \mu \mathrm{M})+2,4-\mathrm{D}(28.73 \mu \mathrm{M})$. Ascorbic acid $\left(150 \mathrm{mg} \cdot \mathrm{L}^{-1}\right)$ of were added to the medium to avoid oxidation, according to Werner et al [26]. The tubes were maintained at $25^{\circ} \mathrm{C}$ in the dark in a Biochemical oxygen demand chamber (B.O.D). For the determination of the increase in callus fresh mass, the difference between the mass at 90 days of incubation and the initial mass (mass before the subculture) was determined.

\section{Phytochemical Analyses}

For the extraction, $100 \mathrm{mg}$ callus from the different treatments were collected. The samples were then macerated in $1 \mathrm{~mL}$ methanol and kept under constant stirring at $223 \mathrm{rpm}$ for 2 hours on a Marconi MA-420 orbital shaker. Subsequently, the samples were centrifuged for 30 minutes at $14000 \mathrm{rpm}$. The supernatant was collected. The operation was repeated until the supernatant became colorless. The extracts were suitably mixed and dried at $45^{\circ} \mathrm{C}$.

Total phenolic compounds was determined as described by Ainsworth and Gillespie as follows [27]. Aliquots of the extracts $(250 \mu \mathrm{L})$ were mixed with $1.25 \mathrm{~mL}$ of $10 \%$ Folin-Ciocalteu reagent. After 8 minutes, $1.0 \mathrm{~mL}$ of $4 \%$ sodium carbonate was added. The samples were incubated for 2 hours in the dark. Absorbance was measured at $740 \mathrm{~nm}$. The phenolic concentration was calculated from a standard curve of gallic acid. 
To determine the total flavonoids content, aliquots of the extracts $(250 \mu \mathrm{L})$ were mixed with $2.44 \mathrm{~mL}$ of $80 \%$ ethanol, $50 \mu \mathrm{L}$ of potassium acetate $(1 \mathrm{M})$ and $50 \mu \mathrm{L}$ aluminum nitrate (10\%). The samples were then incubated for 40 minutes at room temperature. Absorbance was measured at $415 \mathrm{~nm}$. The concentration of flavonoids was calculated from a standard quercetin curve [28]. For both, phenolics and flavonoids, appropriated blanks were run in paralell.

The analysis of fukugetin and 7-epiclusianone was performed by high performance liquid chromatography in a Shimadzu LC-100 chromatograph, as described by Santa-Cecília et al [29]. The identification of compounds was made based on retention time and absorption spectrum of Garcinia brasiliensis compounds previously isolated and characterized. All analyses were performed with callus at $90^{\text {th }}$ days of cultivation after the subculture.

\section{Experimental Design and Statistical Analyses}

The experimental design was completely randomized, with 5 SA concentrations $(0 ; 0.1$; $1 ; 10$ and $100 \mu \mathrm{M})$ in the presence and in the absence of the growth regulators 2-iP $(72 \mu \mathrm{M})$ $+2,4-\mathrm{D}(28.73 \mu \mathrm{M})$, using 10 replicates for the obtention of fresh callus mass and 5 replicates for the phytochemical analyses. The data were submitted to analysis of variance at $5 \%$ significance by the Scott-Knott test, using the program Sisvar [30].

\section{RESULTS AND DISCUSSION}

\section{Phytochemical Analyses}

Several studies have shown that polyphenols present in medicinal plants, especially flavonoids, have aroused great interest in research due to their medicinal properties [31,11]. These compounds are among the most studied class of secondary metabolites, making them desirable targets for in vitro culture [32].

In this context, the table 1 presents the total content of phenolic and flavonoids compounds in callus of Garcinia brasiliensis zygotic embryos, subcultured at different salicylic acid (SA) concentrations, in the presence or in the absence of the growth regulators 2,4-D and 2-iP. It can be observed that the highest concentration of total phenolic compounds occurred in the treatment with $100 \mu \mathrm{M}$ SA in callus subcultured in the absence of 2,4-D and 2-iP, and with $10 \mu \mathrm{M} \mathrm{SA}$ in callus subcultured in the presence of these regulators. Such result may be associated with the interactions of SA and phytohormones [33]. Anyway, SA showed a secondary metabolism elicitor effect as reported in the literature, especially in in vitro conditions $[34,35,36]$. It should be noted that a low concentration of phenolics was observed in the control, in the absence of 2,4-D and 2-iP. The lack of auxin and cytokinin may have had a negative influence on total phenolic production in callus, since studies by Aremu et al. [37] reported 12 types of bioactive phenolic compounds in Tulbaghia simmleri Beauverd, also with medicinal properties, and found that their occurrence, distribution and levels were strongly influenced by the treatment with cytokinins, emphasizing the importance of these molecules in the biosynthesis route of these compounds. It is important to highlight that control containing 2,4-D and 2-iP had a significantly higher amount of total phenolics when compared to the control in the absence of these regulators, showing the importance of auxin and cytokinin in the culture media. On the 
other hand, the concentration $100 \mu \mathrm{M}$ SA without the 2,4-D and 2-iP favored phenolic increase. This shows that media not supplemented with 2,4-D and 2-iP needed a higher concentration of the elicitor (Table 1).

Table 1. Total phenolics content in Garcinia brasiliensis callus subcultured with SA in the absence and presence of $72 \mu \mathrm{M}$ of 2-iP and $28.73 \mu \mathrm{M}$ of 2,4-D.

\begin{tabular}{ccc}
\hline Treatments & \multicolumn{2}{c}{ Total Phenolics content $\left(\boldsymbol{\mu g} \mathbf{~ m}^{-1} \mathbf{D W}\right)$} \\
\cline { 2 - 3 }$(\mathbf{S A})$ & Without 2,4-D and 2-iP & With 2,4-D and 2-iP \\
\hline Control & $50.2 \mathrm{c}$ & $153.6 \mathrm{~b}$ \\
$0.1 \mu \mathrm{M}$ & $121.3 \mathrm{~b}$ & $134.1 \mathrm{~b}$ \\
$1 \mu \mathrm{M}$ & $129.3 \mathrm{~b}$ & $129.0 \mathrm{~b}$ \\
$10 \mu \mathrm{M}$ & $127.0 \mathrm{~b}$ & $291.0 \mathrm{a}$ \\
$100 \mu \mathrm{M}$ & $268.1 \mathrm{a}$ & $145.8 \mathrm{~b}$ \\
\hline
\end{tabular}

Same letters indicate that values do not differ by the Scott-Knott test at the $5 \%$ significance level.

Concerning flavonoids content, the levels was higher when compared to the phenolic compounds. This may be related to the large amount of biflavonoids produced by the Clusiaceae family, particularly in Garcinia [5] and, furthermore, because the solvent methanol does not extract all phenolic compounds present on the surface of callus cells [38]. In callus subcultured in the absence of auxin and cytokinin, there was significant difference in the concentration $100 \mu \mathrm{M}$ AS (Table 2), indicating that highest concentration SA did influence the contents of these compounds. On the other hand, in the presence of 2,4-D and 2-iP, it was observed that auxin and cytokinin supplementation without the presence of the elicitor, was sufficient for the significant increase in flavonoids. Auxins and cytokinins may affect the production of these compounds by regulating initial steps of the chiquimate/phenylpropanoid pathway [39]. In the medicinal plant Merwilla plumbea Lindl., under in vitro conditions, 2-iP provided an increase in the production of caffeic acid Studies [40] and in callus of Aronia melanocarpa, both auxins and cytokinins significantly influence the production of free phenolic acids [41]. These results imply that the in vitro production of bioactive secondary metabolites, especially flavonoids, in callus of Garcinia brasiliensis was significantly influenced by the exogenous addition of different types and concentrations of cytokinins and auxins, and that the interaction between the elicitor SA and 2,4-D and 2-iP negatively affected flavonoid production, regardless of their concentration (Table 2). 
Table 2. Total flavonoids content in Garcinia brasiliensis callus subcultured with SA in the absence and presence of $72 \mu \mathrm{M}$ of $2-\mathrm{iP}$ and $28.73 \mu \mathrm{M}$ of 2,4-D.

\begin{tabular}{ccc}
\hline \multirow{2}{*}{$\begin{array}{c}\text { Treatments } \\
\text { (SA) }\end{array}$} & \multicolumn{2}{c}{$\begin{array}{c}\text { Total Flavonoids content } \\
\left(\mu \mathbf{~ m g ~ m}^{-1} \mathbf{~ D W}\right)\end{array}$} \\
\cline { 2 - 3 } & Without 2,4-D and 2-iP & $\begin{array}{c}\text { With 2,4-D } \\
\text { and 2-iP }\end{array}$ \\
\hline Control & $145.9 \mathrm{~b}$ & $438.2 \mathrm{a}$ \\
$0.1 \mu \mathrm{M}$ & $188.6 \mathrm{~b}$ & $179.4 \mathrm{~b}$ \\
$1 \mu \mathrm{M}$ & $156.3 \mathrm{~b}$ & $169.2 \mathrm{~b}$ \\
$10 \mu \mathrm{M}$ & $197.9 \mathrm{~b}$ & $184.3 \mathrm{~b}$ \\
$100 \mu \mathrm{M}$ & $333.9 \mathrm{a}$ & $160 \mathrm{~b}$ \\
\hline
\end{tabular}

Same letters indicate that values do not differ by the Scott-Knott test at the $5 \%$ significance level.

Different hormones have some type of interaction with SA [42]. Crosstalk among different phytohormones results in synergistic and antagonistic interactions and plays an essential role in plant response to abiotic stress [43]. Auxin, for example, has an antagonistic interaction with salicylic acid [44]. This crosstalk between SA and auxin 2,4-D helps explain the significant reduction in flavonoid production, when compared to the control (Table 2). Additionally, the production of fukugetin and 7-epiclusianone was evaluated. As shown in Table 3, in most treatments, it was possible to identify these molecules. However, the variation in levels was very high, especially for the fukugetin. Therefore, in most treatments, there was no statistically difference. Except for the treatment with $10 \mu \mathrm{M} \mathrm{SA}$ with 2,4-D and 2-iP, where there was a significant increase in 7-epiclusianone, in which the addition of regulators 2,4-D and 2-iP favored the significant increase in this benzophenone, when compared to the medium without growth regulators.

This increase in the levels of 7-epiclusianone may be associated with the increase in phenolic compounds (Table1). Such response shows that the metabolic pathways of the cell responsible for the synthesis of this benzophenone remained active in the callus [3]. The 7-epiclusianone is important in the prevention and treatment of cancer by induction of apoptosis and cell cycle blocking in G1 phase, preventing the transcription and translation of important cell cycle regulators involved in the progression of cancer cells [45]. It also has anti-HIV [46] and anti-anaphylactic [12] properties. Studies involving the antimicrobial activity of epiclusianone in Garcinia brasiliensis seeds showed that this compound has antifungal and antibacterial activities [13]. 
Table 3. Contents of fukugetin and 7-epiclusianone in Garcinia brasiliensis callus subcultured with SA in the absence and presence of $72 \mu \mathrm{M}$ of 2-iP and $28.73 \mu \mathrm{M}$ of 2,4-D.

\begin{tabular}{ccccc}
\hline \multirow{2}{*}{$\begin{array}{c}\text { Treatments } \\
\text { (SA) }\end{array}$} & \multicolumn{2}{c}{$\begin{array}{c}\text { Fukugetin } \\
\left(\mu \mathbf{~ m g}^{-1} \mathbf{~ D W}\right)\end{array}$} & \multicolumn{2}{c}{$\begin{array}{c}\text { 7-epiclusianone } \\
\left(\mu \mathbf{~ m g}^{-1} \mathbf{~ D W}\right)\end{array}$} \\
\cline { 2 - 5 } & $\begin{array}{c}\text { Without 2,4-D } \\
\text { and 2-iP }\end{array}$ & $\begin{array}{c}\text { With 2,4-D } \\
\text { and 2-iP }\end{array}$ & $\begin{array}{c}\text { Without 2,4-D } \\
\text { and 2-iP }\end{array}$ & $\begin{array}{c}\text { With 2,4-D } \\
\text { and 2-iP }\end{array}$ \\
\hline Control & $79.6 \mathrm{~b}$ & n.i & $117.1 \mathrm{~b}$ & $\mathrm{n} . \mathrm{i}$ \\
$0.1 \mu \mathrm{M}$ & $216.3 \mathrm{~b}$ & $103.6 \mathrm{~b}$ & $135.1 \mathrm{~b}$ & $96.7 \mathrm{~b}$ \\
$1.0 \mu \mathrm{M}$ & $57.4 \mathrm{~b}$ & $39.9 \mathrm{~b}$ & $94.3 \mathrm{~b}$ & $132.9 \mathrm{~b}$ \\
$10 \mu \mathrm{M}$ & $17.5 \mathrm{~b}$ & $149.1 \mathrm{~b}$ & $166.0 \mathrm{~b}$ & $803.6^{\mathrm{a}}$ \\
$100 \mu \mathrm{M}$ & $\mathrm{n} . \mathrm{i}$ & n.i & $130.7 \mathrm{~b}$ & $125.3 \mathrm{~b}$ \\
\hline
\end{tabular}

Same letters indicate that values do not differ by the Scott-Knott test at the $5 \%$ significance level. N.i.: not identified.

\section{Callus Fresh Mass}

The addition of growth regulators, such as 2,4-D and 2-iP, is often required for callus growth, since they induce different responses in cells, including increased levels of proteins and mitotic activity [47].

In fact, the callus fresh mass was higher in the control with growth regulators when compared to that without theese substances (Table 4). In the treatments without 2-iP and 2,4-D, SA did not cause changes in the callus fresh mass. However in the presence of the auxin and cytokinin there was a decrease in callus fresh mass in the treatments with 10 and 100 uM SA. Similar results were observed by Rezaei et al. [48] who verified that increased SA concentration resulted in a significant decrease in viability and cell growth, when compared to culture media without the presence of SA in Taxus baccata L. and Dong et al.[49], in which elicitation with SA resulted in a reduction in the mass of Salvia miltiorrhiza Bunge cells concomitant with the increased accumulation of phenolic compounds through the stimulation of PAL activity [50].

Table 4. Fresh mass of Garcinia brasiliensis calluses exposed to salicylic acid in the absence and presence of 2,4-D and 2-iP.

\begin{tabular}{ccc}
\hline \multirow{2}{*}{$\begin{array}{c}\text { Treatments } \\
\text { (SA) }\end{array}$} & \multicolumn{2}{c}{ Callus fresh mass $(\mathbf{m g})$} \\
\cline { 2 - 3 } & $\begin{array}{c}\text { Without 2,4-D } \\
\text { and 2-iP }\end{array}$ & $\begin{array}{c}\text { With 2,4-D } \\
\text { and 2-iP }\end{array}$ \\
\hline Control & $9.6 \mathrm{c}$ & $30.8 \mathrm{a}$ \\
$0.1 \mu \mathrm{M}$ & $6.0 \mathrm{c}$ & $29.5 \mathrm{a}$ \\
$1 \mu \mathrm{M}$ & $8.5 \mathrm{c}$ & $25.5 \mathrm{ab}$ \\
$10 \mu \mathrm{M}$ & $9.2 \mathrm{c}$ & $12.8 \mathrm{bc}$ \\
$100 \mu \mathrm{M}$ & $10.3 \mathrm{c}$ & $15.2 \mathrm{bc}$ \\
\hline
\end{tabular}

Same letters indicate that values do not differ by the Scott-Knott test at the $5 \%$ significance level

Funding: This study was supported by Coordenação de Aperfeiçoamento de Pessoal de Nível Superior (CAPES, Grant AUX PE-PNPD-2297.2011), Fundação de Amparo a 
Pesquisa do Estado de Minas Gerais (FAPEMIG grant APQ- 01671-09) and Conselho Nacional de Desenvolvimento Científico e Tecnológico (CNPq).

Conflicts of Interest: The authors declare no conflict of interest

\section{REFERENCES}

1. Chin, Y.; Kinghorn, A.D. Structural characterization, biological effects, and synthetic studies on xanthones from mangosteen (Garcinia mangostana), a popular botanical dietary supplement. Mini-Review in Org Chem 2008, 5, 355-364.

2. Santa-Cecília, F.V.; Abreu, F.A.; Silva, M.A.; Castro, E.M.; Santos, M.H. Estudo farmacobotânico das folhas de Garcinia brasiliensis Mart. (Clusiaceae). Rev Bras PI Med 2013, 15(3), 397-404.

3. Santos Filho, P.R.; Santos, B.R.; Barbosa, S.; Vieira, L.R.; Freitas, N.C.; Dias, D.F.; et al. Growth curve, biochemical profile and phytochemical analyses in calli obtained from the procambium segments of Bacupari. Braz Arch Biol Technol 2014, 57(3), 326-333.

4. Häfner, A.; Frahm, A.W. Biflavanoids from the heartwood of Garcinia schomburgkiana and their structural elucidation as atropisomers. Planta Med 1993, 59(1), 604-604.

5. Ferreira, R.O.; Carvalho, M.G.; Silva, T.M.S. Ocorrência de biflavonoides em Clusiaceae: aspectos químicos e farmacológicos. Quim Nova 2012, 35(11), 2271-2277.

6. Santos, M.H.; Nagem, T.J.; Oliveira, T.T.; Braz-Filho, R. 7-Epiclusianona, a nova benzofenona tetraprenilada e outros constituintes químicos dos frutos de Rheedia gardneriana. Quím. Nova 1999, 22(5), 654-660.

7. Assis, D.M.; Gontijo, V.S.; Pereira, I.O.; Santos, A.N.; Camps, I.; Nagem, T.J.; et al. Inhibition of cysteine proteases by a natural biflavone: behavioral evaluation of fukugetin as papain and cruzain inhibitor. J Enzyme Inhib Med 2012, 28(4), 661-670.

8. Gontijo, V.S.; Judice, W.A.; Codonho, B.; Pereira, I.O.; Assis, D.M.; Januário, J.P.; et al. Leishmanicidal, antiproteolytic and antioxidant evaluation of natural biflavonoids isolated from Garcinia brasiliensis and their semisynthetic derivatives. Eur J Med Chem 2012, (58), 613-623.

9. Pereira, I.O.; Assis, D.M.; Juliano, M.A.; Cunha, R.L.; Barbieri, C.L.; Sacramento, L.V.; et al. Natural products from Garcinia brasiliensis as Leishmania protease inhibitors. J Med Food 2011, 14(6), 557-562.

10. Verdi, L.G.; Pizzolatti, M.G.; Montanher, A.B.; Brighente, I.M.; Smânia Júnior, A.; Smânia, E.E.; et al. Antibacterial and brine shrimp lethality tests of biflavonoids and derivatives of Rheedia gardneriana. Fitoterapia 2004, 75(3), 360-363.

11. Arwa, P.S.; Zeraik, M.L.; Ximenes, V.F.; Fonseca, L.M.; Silva, B.V.; Silva, D.H.S. Redox-active biflavonoids from Garcinia brasiliensis as inhibitors of neutrophil oxidative burst and human erythrocyte membrane damage. J Ethnopharmacol 2015, 174, 410-418.

12. Neves, J.S.; Coelho, L.P.; Cordeiro, R.S.; Veloso, M.P.; Rodrigues e Silva, P.M.; Santos, M.H.; et al. Antianaphylactic properties of 7-epiclusianone, a tetraprenylated benzophenone isolated from Garcinia brasiliensis. Planta Med 2007, 73(7), 644-649.

13. Naldoni, F.J.; Claudino, A.L.R.; Cruz, J.W.; Chavasco, J.K.; Faria e Silva, P.M.; Veloso, M.P.; et al. Antimicrobial activity of benzophenones and extracts from the fruits of Garcinia brasiliensis. J Med Food 2009, 12(2), 403-407. 
14. Coelho, L.P.; Serra, M.F.; Pires, A.L.; Cordeiro, R.S.; Rodrigues e Silva, P.M.; Santos, M.H.; et al. 7-Epiclusianone, a tetraprenylated benzophenone, relaxes airway smooth muscle through activation of the nitric oxide-cGMP pathway. J Pharmacol Exp Ther 2008, 327(1), 206-214.

15. Murata, R.M.; Yatsuda, R.; Santos, M.H.; Konh, L.K.; Martins, F.T.; Nagem, T.J.; et al. Antiproliferative effect of benzophenones and their influence on cathepsin activity. Phytother Res 2010, 24(3), 379-383

16. Pereira, I.O.; Marques, M.J.; Pavan, A.L.; Codonho, B.S.; Barbiéri, C.L.; Beijo, L.A.; et al. Leishmanicidal activity of benzophenones and extracts from Garcinia brasiliensis Mart. Fruits. Phytomedicine 2010, 17(5), 339-345.

17. Fumagali, E.; Gonçalves, R.A.C.; Machado, M.F.P.S.; Vidoti, G.J.; Oliveira, A.J.; Produção de metabólitos secundários em cultura de células e tecidos de plantas: $O$ exemplo dos gêneros Tabernaemontana e Aspidosperma. Braz J Pharmacogn 2008, 18(4), 627-641.

18. Giri, C.C.; Zaheer, M. Chemical elicitors versus secondary metabolite production in vitro using plant cell, tissue and organ cultures: recent trends and a sky eye view appraisal. Plant Cell Tiss Cult 2016, 126, 1-18.

19. Pérez-Alonso, N.L.; Labrada, F.A.; Pérez, A.C.; Pérez, A.P.; Sosa, R.; Mollineda, A.; et al. Estimulación de cardenólidos en brotes de Digitalis purpurea $\mathrm{L}$. cultivados in vitro mediante elicitores. Rev Colomb Biotecnol 2014, 16(1), 51-61.

20. Hayat, Q.; Hayat, S.; Irfan, M.; Ahmad, A.; Effect of exogenous salicylic acid under changing environment: A review. Envir Exp Bot 2010, 68(1), 14-25.

21. Sakhabutdinova, A.R.; Fatkhutdinova, D.R.; Bezrukova, M.V.; Shakirova, F.M.; Salicylic acid prevents the damaging action of stress factors on wheat plants. Bulg J Plant Physiol 2003, Special Issue, 314- 319.

22. Yan, S.; Wang, W.; Marqués, J.; Mohan, R.; Saleh, A.; Durrant, W.E.; et al. Salicylic acid activates DNA damage responses to potentiate plant immunity. Mol cell, 2013, 52(4), 602-610.

23. Orabi, S.A.; Dawood, M.G.; Salman, S.R.; Comparative study between the physiological role of hydrogen peroxide and salicylic acid in alleviating the harmful effect of low temperature o tomato plants grown under sand-ponic culture. Sci Agric. 2015, 1(9), 49-59.

24. Miura, K.; Tada, Y.Y.; Regulation of water, salinity and cold stress responses by salicylic acid. Frontiers in Plant Sci Plant Physiol 2014, 5, 1-12

25. Lloyd, G.; Mccown, B. Commercially-feasible micropropagation of mountain laurel, Kalmia latifolia, by use of shoot-tip culture. Comb Proc Int Plant Prop Soc 1980, 30, 421-427.

26. Werner, E.T.; Pessotti, K.V.; Lopes, F.P.; Cuzzuol, G.R.F. Indução da calogênese de Caesalpinia echinata Lam. (pau-brasil) in vitro. Rev Bras Biocien 2007, 5, 1053-1055.

27. Ainsworth, E.A.; Gillespie, K.M. Estimation of total phenolic content and other oxidation substrates in plant tissues using Folin-Ciocalteu reagent. Nature Protocols 2007, 2, 875-877.

28. Park, Y.K.; Koo, M.H.; Ikegaki, M.; Contado, J.L. Comparison of the flavonoid aglycone contents of Apis mellifera propolis from various regions of Brazil. Arq Biol Tecnol 1997, 40, 97-106.

29. Santa-Cecília, F.V.; Freitas, L.A.S.; Vilela, F.C.; Veloso, C.C.; Rocha, C.Q.; Moreira, M.E.C.; et al. Antinociceptive and anti-inflammatory properties of 7-epiclusianone, a prenylated benzophenone from Garcinia brasiliensis. Eur J Pharmacol 2011, 670, 280-285.

30. Ferreira, D.F. Sisvar: A Guide for its Bootstrap procedures in multiple comparisons. Cienc Agrotecnol 2014, 38(2), 109-112. 
31. Zeraik, M.L.; Serteyn, D.; Deby-Dupont, G.; Wauters, J.N.; Tits, M.; Yariwake, J.H.; et al. Evaluation of the antioxidante activity of passion fruit (Passiflora edulis and Passiflora alata) extracts on stimulate dneutrophils and myeloperoxidase activity assays. Food Chem 2011, 128, 259-265.

32. Matkowski, A. Plant in vitro culture for the production of antioxidants a review. Biotechnol. Adv 2008, 26, 548-560.

33. Deb, A.; Grewal, R.K.; Kundu, S. Regulatory cross-talk and cascades in rice hormone biosynthesis pathways contirbute to stress signalling. Front Plant Sci 2016, 7, 1303-1312.

34. Naik, P.M.; Al-Khayri, J.M. Impact of abiotic elicitors on in vitro production of plant secondary metabolites: A review. J AdvRes Biotechnol 2016, 1(1), 1-7.

35. Amanullah, M.M.; Sekar, S.; Vincent, S. Plant growth substances in crop production. Asian J. Plant Sci 2010, 9, 215-222.

36. Zhao, J.; Davis, L.T.; Verpoort, R. Elicitor signal transduction leading to production of plant secondary metabolites. Biotechnol. Adv 2005, 23, 283-333.

37. Aremu, A.O.; Plačková, L.; Gruz, J.; Bíba, O.; Šubrtová, M.; Novák, O.; et al. Accumulation pattern of endogenous cytokinins and phenolics in different organs of 1-year-old cytokinin pré-incubated plants: implications for conservation. Plant Biol 2015 17, 1146-1155.

38. El-Baz, F.K.; Mohamed, A.A.; Ali, S.I. Callus formation, phenolics content and related antioxidant activities in tissue culture of a medicinal plant colocynth (Citrullus colocynthis). Nova Biotecnol 2010, 10(2), 79-94.

39. Cheynier, V.; Comte, G.; Davies, K.M.; Lattanzio, V.; Martens, S. Plant phenolics: recent advances on their biosynthesis, genetics, and ecophysiology. Plant Physiol. Biochem 2013, 72, 1-20. 40. Aremu, A.O.; Gruz, J.; Šubrtová, M.; Szüčová, L.; Doležal, K.; Bairu, M.W.; et al. Antioxidant and phenolic acid profiles of tissue cultured and acclimatized Merwilla plúmbea plantlets in relation to the applied cytokinins. J Plant Phisiol 2013, 170,1303-1308.

41. Szopa, A.; Ekiert, H.; Muszyńska. Accumulation of hydroxybenzoic acid and other biologically active phenolic acids in shoot and callus cultures of Aronia melanocarpa (Michx.) Elliott (Black chokeberry). Plant Cell Tiss Cult 2013, 113, 323-329.

42. Vlot, A.C.; Dempsey, D.A.; Klessig, D.F. Salicylic acid, a multifaceted hormone to combat disease. Annu Rev Phytopathol 2009, 47, 177-206.

43. Peleg, Z.; Blumwald, E. Hormone balance and abiotic stress tolerance in crop plants. Curr. Opin. Plant Biol 2011, 14, 290-295.

44. Nassem, M.; Srivastava, M.; Tehseen, M.; Ahmed, N. Auxin crosstalk to plant immune networks: a plant-pathogen interaction perspective. Curr Protein Pept Sci 2015, 16(5), 389-394.

45. Protiva, P.; Hopkins, M.E.; Baggett, S.; Yang, H.; Lipkin, M.; Holt, P.R.; et al. Growth inhibition of colon cancer cells by polyisoprenylated benzophenones is associated with induction of the endoplasmic reticulum response. Int J Cancer 2008, 123, 687-694.

46. Piccinelli, A.L.; Cuesta-Rubio, O.; Chica, M.B.; Mahmood, N.; Pagano, B.; Pavone, M.; et al. Structural revision of clusianone and 7-epi-clusianone and anti-HIV activity of polyisoprenylated benzophenones. Tetrahedron 2005, 61, 8206-8211.

47. Zarghami, M.; Shoor, M.; Ganjali, A.; Moshtaghi, N.; Tehranifar, A. Effect of salicylic acid on morphological and ornamental characteristics of petunia hybrida at drought stress. Ind $J$ Fund Appl Life Sci 2014, 4, 523-532. 
48. Rezaei, A.; Ghanati, F.; Dehaghi, M.A. Stimulation of taxol production by combined salicylic acid elicitation and sonication in Taxus baccata cell culture. Int Conf Life Sci Technol 2011, 3,193-197. 49. Dong, J.; Wan, G.; Liang, Z. Accumulation of salicylic acid-induced phenolic compounds and raised activities of secondary metabolic and antioxidative enzymes in Salvia miltiorrhiza cell culture. $J$ Biotecnol 2010, 148, 99-104.

50. Yan, Q.; Shi, M, Ng, J.; Wu, J.Y. Elicitor-induced rosmarinic acid accumulation and secondary metabolism enzyme activities in Salvia miltiorrhiza hairy roots. Plant Sci 2006, 170, 853-858.

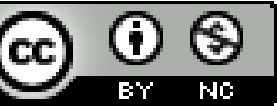

2018 by the authors. Submitted for possible open access publication under the terms and conditions of the Creative Commons Attribution (CC BY NC) license (https://creativecommons.org/licenses/by-nc/4.0/). 